\title{
Effects of ketogenic diet intervention on selected obese IIUM students during Ramadhan
}

\author{
${ }^{1}$ Wan Ali Munawar, W.A.H., ${ }^{1, *}$ Amid. A. and ${ }^{2}$ Abdullah, A. \\ ${ }^{1}$ International Institute for Halal Research and Training INHART, Level 3, KICT Building, International \\ Islamic University Malaysia, Jalan Gombak, 53100 Kuala Lumpur \\ ${ }^{2}$ Kulliyyah of Medicine, International Islamic University Malaysia, Bandar Indera Mahkota Campus, Jalan \\ Sultan Ahmad Shah, 25200 Kuantan, Pahang Darul Makmur
}

\author{
Article history: \\ Received: 23 August 2019 \\ Received in revised form: 4 \\ October 2019 \\ Accepted: 12 December 2019 \\ Available Online: 10 \\ February 2020
}

Keywords:

Fasting,

Ketogenic diet,

Obesity,

Ramadan

DOI:

https://doi.org/10.26656/fr.2017.4(S1).S20

\begin{abstract}
Obesity and overweight are one of the main problems faced by Malaysian society due to sedentary lifestyle and high-carbohydrate consumption. A "low glycemic diet" is suggested as a suitable alternative in preventing obesity, because of its low carbohydrate intake which can be referred to as Atkins or Ketogenic diet (KD). A case study was carried out to assess the effect of KD during Ramadan on obese individuals. KD meal intervention was developed upon consultation with a dietician and tailored for Sahur (a pre-dawn meal) and Iftar (evening meal for breaking fast). A total of six participants were involved in this study which consists of 2 groups. A control group of 3 selected obese male IIUM students received no specific diet, and a study group of 3 selected obese male IIUM students underwent KD meal intervention. The KD meal intervention was carried out one week before Ramadan to allow the participants' body to familiarize with high fat and low carbohydrate diet. Results showed that most of the selected obese participants who applied KD meal intervention exhibited satisfactory results in weight and Body Mass Index (BMI) reduction, steady levels of blood glucose, normal blood pressure levels and the presence of ketone bodies at a $p$-value $<0.01$. However, the participants in the control group showed no significant changes at $\mathrm{p}<0.01$ in weight, BMI, blood glucose levels, blood pressure and not a trace of ketone bodies. The findings of this study indicated that KD showed a positive effect on obesity control when conducted during Ramadan fasting.
\end{abstract}

\section{Introduction}

Nutrition is vital for health. Undernourishment was a significant burden on human health in the past. However, human morbidity and mortality increase not only with undernourishment but also with overnutrition. Overnutrition leads to obesity that is a medical condition that occurs due to excessive adipose tissue in the body (Brook et al., 1972). Obesity is increasingly prevalent worldwide and the dramatic increase in the prevalence of obesity in Malaysia over the last three decades was documented clearly since large scale population data became available. In the global context, alongside development and prosperity, in many countries especially in Asia, obesity has become a leading health issue. This process is termed "nutrition transition", a shift from low availability of calories mainly in the form of plant products to diets that are high in fats, sugars, and energy-dense processed foods. This, in turn, is the result of rapid economic development which has taken place in countries such as Malaysia in the last quarter of the twentieth century. Malaysian are ranked highest in obesity among Southeast Asia countries (Lim, 2016). Obesity and overweight are one of the main problems faced by Malaysian society due to sedentary lifestyle and high-carbohydrate consumption. Obesity is preventable by following a diet which helps in promoting healthier eating habits coupled with a regular exercise routine (AlJazzaf, 2007). However, an optimum and specific diet catered to treat obesity has yet to be found.

A "low glycemic diet" is suggested as a suitable alternative in preventing obesity, because of its low carbohydrate intake which can be referred to as Atkins or Ketogenic diet (KD). The KD is a low carbohydrate diet with daily consumption of carbohydrate of less than $20 \mathrm{~g}$ per serving, with emphasis on more consumption of high -fat foods either in proteins, vegetables and others. The effect of a ketogenic diet has been tested on obese adult rats and adolescent humans (Dashti et al., 2004; $\mathrm{Hu}$ et al., 2012; Hussain et al., 2012; Stafstrom and Rho, 2012). Nonetheless, the effects of KD on obese adults or 
young adults are still unknown and yet to be tested.

Fasting is one option for achieving weight loss (Johnstone, 2015). Fasting is proven to reduce the secretion of insulin-like growth factor (IGF-1), a hormone that promotes colorectal, breast and prostate cancers. Therefore, a combination of a low carbohydrate diet and fasting is expected to enhance the process of bodyweight reduction and provide an additional health benefit. The aim of this study was to adopt KD during Ramadan on selected obese IIUM students and determine its effects on body weight. It also intended to develop a KD meal intervention plan that was tailored for Sahur (a pre-dawn meal) and Iftar (evening meal for breaking fast).

\section{Materials and methods}

\subsection{Study design}

A case study was carried out for four weeks involving six participants selected from obese IIUM Gombak students. Data of the obese participants can be seen in Table 1. Their obesity level was determined by using the BMI formula and if a participant's BMI is greater than 30 , they are considered as obese. Three participants were chosen for KD meal intervention, while a control group of 3 selected obese IIUM Gombak students were observed without any diet intervention throughout the same study period. All selected participants were healthy and free from any medical illness. The participants demographic after the research is displayed in Table 2.

\subsubsection{Intervention method}

A special ketogenic diet was developed specifically for Sahur and Iftar during Ramadhan, which was developed upon consultation with a dietician. The diet intervention was started one week before Ramadhan until one week before Syawal (end of Ramadhan). This is to allow the participants' body to familiarize with the high fat and low carbohydrate diet. The intervention was stopped a week before Syawal to enable participants to return to their hometowns.

\subsubsection{Diet plan}

KD meal plans for Ramadan were developed for the participants in the diet intervention group. Meal plans have been sent to UNIPEQ lab at Universiti Kebangsaan Malaysia to reflect their actual nutritional information. The diet meal plan during Ramadhan consists of two meals which are for Sahur and Iftar that were determined by the rotation of the meals in the previous diet meal plan stated in Table 3 below.

\subsubsection{Parameter monitoring}

During the period of 4 weeks, various parameters such as body weight, body mass index, blood glucose levels and the presence of ketone bodies were monitored. These measurements were recorded on every Friday during the diet intervention.

\subsubsection{Ketone measurement}

The participants' ketone bodies were measured using a urinary test strip (URS-1K, Malaysia). The ketones were measured based on the color that appears on the test strip. The test strip measured $\beta$-hydroxybutyric acid (BHB), the predominant ketone in the body, rather than acetoacetate or acetones. Ketones were determined in this research because ketone production is triggered when consuming a ketogenic diet. Ketones produced a purple color on the test strip.

Table 1. Participants Demographic

\begin{tabular}{|c|c|c|c|c|c|c|c|c|}
\hline & Age & Weight (kg) & BMI & Waist circumference (mm) & $\begin{array}{c}\text { Blood } \\
\text { pressure }\end{array}$ & $\begin{array}{c}\text { Blood glucose } \\
(\mathrm{mmol} / \mathrm{l})\end{array}$ & $\begin{array}{c}\text { Water intake } \\
\text { (liter) }\end{array}$ & $\begin{array}{l}\text { Ketone } \\
\text { levels }\end{array}$ \\
\hline A & 25 & 95 & 30.32 & 37 & $124 / 75$ & 6 & nil & Nil \\
\hline $\mathrm{B}$ & 28 & 101 & 30.16 & 39.5 & $119 / 67$ & 5.3 & nil & Nil \\
\hline $\mathrm{C}$ & 33 & 94 & 31.41 & 44 & $114 / 74$ & 5.4 & nil & Nil \\
\hline A1 & 24 & 85 & 31.22 & 40 & $118 / 65$ & 5.4 & nil & Nil \\
\hline B1 & 26 & 98 & 30.58 & 38 & $115 / 64$ & 5.1 & nil & Nil \\
\hline $\mathrm{C} 1$ & 29 & 73 & 31.59 & 41.8 & $124 / 79$ & 5.7 & nil & Nil \\
\hline
\end{tabular}

Table 2. Participants Demographic after the research

\begin{tabular}{|c|c|c|c|c|c|c|c|c|}
\hline & Age & Weight $(\mathrm{kg})$ & BMI & Waist circumference (mm) & $\begin{array}{c}\text { Blood } \\
\text { pressure }\end{array}$ & $\begin{array}{c}\text { Blood glucose } \\
(\mathrm{mmol} / \mathrm{l})\end{array}$ & $\begin{array}{c}\text { Water intake } \\
\text { (liter) }\end{array}$ & $\begin{array}{r}\text { Ketone } \\
\text { levels } \\
\end{array}$ \\
\hline $\mathbf{A}$ & 25 & 90.3 & 28.82 & 35.5 & $115 / 48$ & 4.2 & 1.85 & 0.5 \\
\hline B & 28 & 95 & 28.36 & 37.8 & $115 / 62$ & 4.2 & 1.70 & 0.5 \\
\hline $\mathbf{C}$ & 33 & 90 & 30.07 & 42 & $115 / 62$ & 4.3 & 1.60 & 1.5 \\
\hline A1 & 24 & 83 & 30.51 & 39 & $117 / 62$ & 5.7 & 2.30 & Nil \\
\hline B1 & 26 & 96.7 & 30.31 & 37 & $115 / 62$ & 5.3 & 2.14 & Nil \\
\hline C1 & 29 & 72 & 31.16 & 41 & $116 / 60$ & 5.3 & 2.30 & Nil \\
\hline
\end{tabular}


Table 3. Ketogenic Diet Meal Plan during the whole period of study

\begin{tabular}{|c|c|c|c|c|c|c|c|}
\hline & Monday & Tuesday & Wednesday & Thursday & Friday & Saturday & Sunday \\
\hline Breakfast & $\begin{array}{c}\text { Riceless } \\
\text { Nasi Lemak } \\
(0.15 \mathrm{kcal})\end{array}$ & $\begin{array}{c}\text { Fried eggs } \\
\text { and sausages } \\
(0.18 \mathrm{kcal})\end{array}$ & $\begin{array}{c}\text { Beef Rendang } \\
\text { and Salad } \\
(0.2 \mathrm{kcal})\end{array}$ & $\begin{array}{c}\text { Fried eggs and } \\
\text { sausages } \\
(0.18 \mathrm{kcal})\end{array}$ & $\begin{array}{c}\text { Riceless Nasi } \\
\text { Lemak } \\
(0.15 \mathrm{kcal})\end{array}$ & $\begin{array}{c}\text { Beef Rendang } \\
\text { and Salad } \\
(0.2 \mathrm{kcal})\end{array}$ & $\begin{array}{c}\text { Riceless Nasi } \\
\text { Lemak } \\
(0.15 \mathrm{kcal})\end{array}$ \\
\hline Lunch & $\begin{array}{l}\text { Beef ball } \\
\text { soup } \\
(0.17 \mathrm{kcal})\end{array}$ & $\begin{array}{c}\text { Curry } \\
\text { Chicken } \\
(0.16 \text { kcal })\end{array}$ & $\begin{array}{c}\text { Roasted } \\
\text { Chicken and } \\
\text { Coleslaw } \\
(0.19 \mathrm{kcal})\end{array}$ & $\begin{array}{l}\text { Curry Chicken } \\
(0.16 \mathrm{kcal})\end{array}$ & $\begin{array}{l}\text { Beef ball } \\
\text { soup } \\
(0.17 \mathrm{kcal})\end{array}$ & $\begin{array}{c}\text { Curry } \\
\text { Chicken } \\
(0.16 \text { kcal })\end{array}$ & $\begin{array}{c}\text { Roasted } \\
\text { Chicken and } \\
\text { Coleslaw } \\
(0.19 \text { kcal })\end{array}$ \\
\hline Dinner & $\begin{array}{c}\text { Grilled Fish } \\
\text { and } \\
\text { Vegetables } \\
(0.18 \mathrm{kcal})\end{array}$ & $\begin{array}{l}\text { Butter } \\
\text { Chicken } \\
\text { Wrap } \\
(0.17 \mathrm{kcal})\end{array}$ & $\begin{array}{c}\text { Fried Fish and } \\
\text { Vegetables } \\
(0.18 \text { kcal })\end{array}$ & $\begin{array}{c}\text { Grilled Fish } \\
\text { and Vegetables } \\
(0.18 \mathrm{kcal})\end{array}$ & $\begin{array}{l}\text { Butter } \\
\text { Chicken } \\
\text { Wrap } \\
(0.17 \mathrm{kcal})\end{array}$ & $\begin{array}{c}\text { Grilled Fish } \\
\text { and } \\
\text { Vegetables } \\
(0.18 \mathrm{kcal})\end{array}$ & $\begin{array}{l}\text { Butter } \\
\text { Chicken } \\
\text { Wrap } \\
(0.17 \mathrm{kcal})\end{array}$ \\
\hline
\end{tabular}

\subsection{Statistical analysis}

Data obtained was expressed in mean \pm standard deviation and analyzed using a paired t-test. A paired ttest was used to compare the means of the parameters measured in the research to find the significance during the data collection period. The paired t-test was conducted using the SPSS Statistics by IBM. The main parameters recorded to find the significance between the ketogenic diet and obesity during Ramadan were weight, body mass index as well as the presence of the ketone bodies. The hypothesis for this test is when the parameters such as weight, body mass index as well as the presence of the ketone bodies are shown to be at a $\mathrm{p}$ level $<0.01$, it is deemed as significant.

\section{Results}

The participants' demographic and baseline measurements such as Body Mass Index (BMI), Systolic Blood Pressure (SBP) and Diastolic Blood Pressure (DBP) are shown in Table 4. BMI was calculated by dividing weight over height in meters squared. According to the BMI index, a BMI of 30 and above is considered Obese, Obese I or Obese II depending on the $\mathrm{BMI}$ value. A BMI below 30 is considered as overweight and a BMI between 18.5-24.9 is the normal BMI level. It is observed that the diet intervention group consisting of participant A, B and C have shown a substantial loss in weight after Ramadan, which has also decreased their
BMI and waist circumference stated in Figures 1-3. All 3 participants showed reduced and stable blood glucose levels throughout the 4-week period (Figure 4). During Ramadan, the presence of ketone bodies was also detected in all 3 participants displayed in Figure 5.

As for the participants in the control group (A1, B1, and $\mathrm{C} 1$ ), as shown in Figures 1-5) their results were comparatively different from the experimental group. Their body weight, BMI, waist circumference and blood glucose levels had no significant reduction before and after Ramadan was determined by comparing the control groups' parameter within their group as also comparing with the experimental group. There was no presence of ketones during this period in the control group. Analysis of the parameters before and after Ramadan for both experimental and control groups are displayed in Tables $5-6$, respectively.

\section{Discussion}

Based on the data collected in this study, subjects in the experimental group have shown a remarkable loss in weight during Ramadhan even though the first week of fasting will usually result in loss of water weight (Khan and Khattak, 2009). The subjects continued to show loss of weight and reduction in waist circumference even after the first week. Waist circumference was recorded once every week because this parameter does not fluctuate its' value as fast as the other parameters

Table 4. Participants' demographic and baseline characteristics

\begin{tabular}{lcccccc}
\hline \multirow{2}{*}{ Variable/Group } & \multicolumn{3}{c}{ Experimental $(\mathrm{n}=3)$} & \multicolumn{3}{c}{ Control $(\mathrm{n}=3)$} \\
\cline { 2 - 7 } & $\mathrm{A}$ & $\mathrm{B}$ & $\mathrm{C}$ & $\mathrm{A} 1$ & $\mathrm{~B} 1$ & $\mathrm{C} 1$ \\
\hline Age, years & 25 & 28 & 33 & 24 & 26 & 29 \\
Weight, $\mathrm{kg}$ & 95 & 101 & 94 & 85 & 98 & 73 \\
BMI, kg/m & 30.32 & 30.16 & 31.41 & 31.22 & 30.58 & 31.59 \\
Waist circumference, cm & 37 & 39.5 & 44 & 40 & 38 & 41.8 \\
Blood glucose, mmol/L & 6.0 & 5.3 & 5.4 & 5.4 & 5.1 & 5.7 \\
SBP, mmHg & 124 & 119 & 114 & 118 & 115 & 124 \\
DBP, mmHg & 75 & 67 & 74 & 65 & 64 & 79 \\
Water intake, L & 0 & 0 & 0 & 0 & 0 & 0 \\
Ketone levels, mmol/L & 0 & 0 & 0 & 0 & 0 & 0 \\
BMI, $\mathrm{kg} / \mathrm{m}^{2}$ after research & 28.82 & 29.32 & 30.07 & 30.51 & 30.31 & 31.16 \\
\hline
\end{tabular}




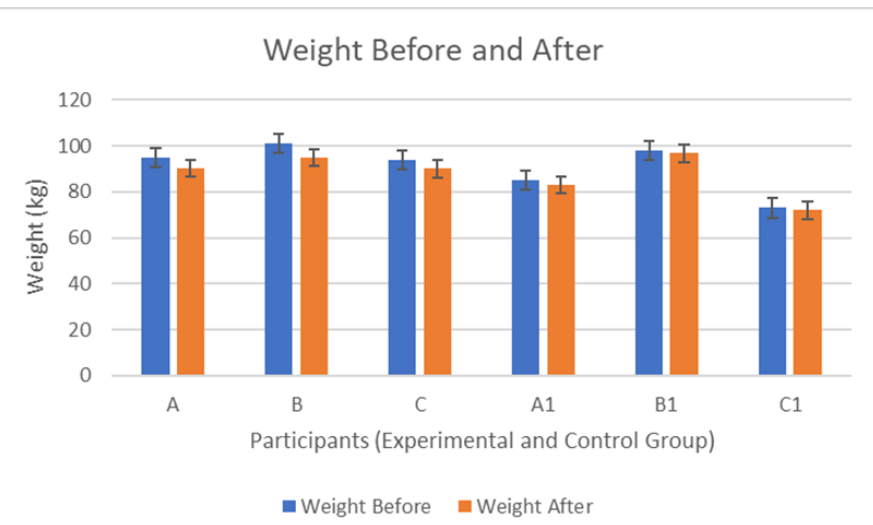

Figure 1. Weight before and after Ramadhan

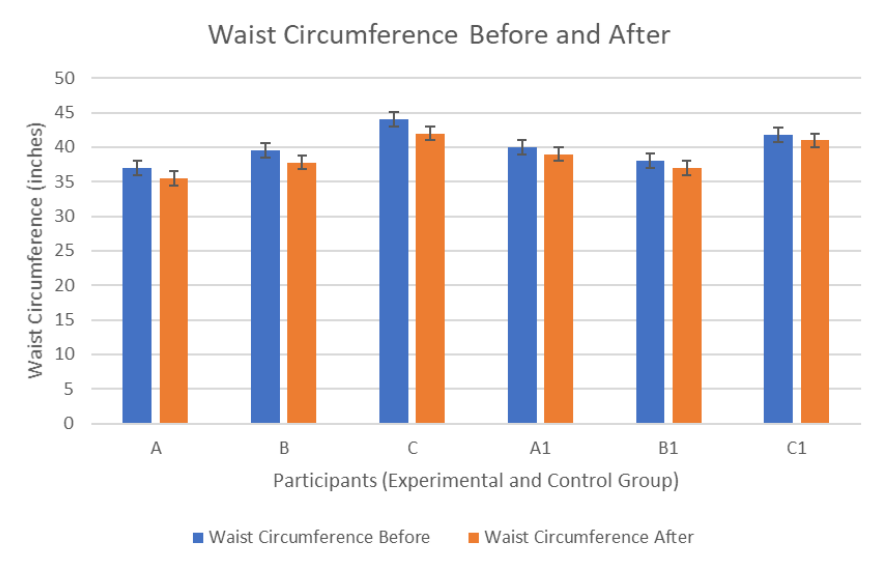

Figure 3. Waist circumference before and after Ramadhan

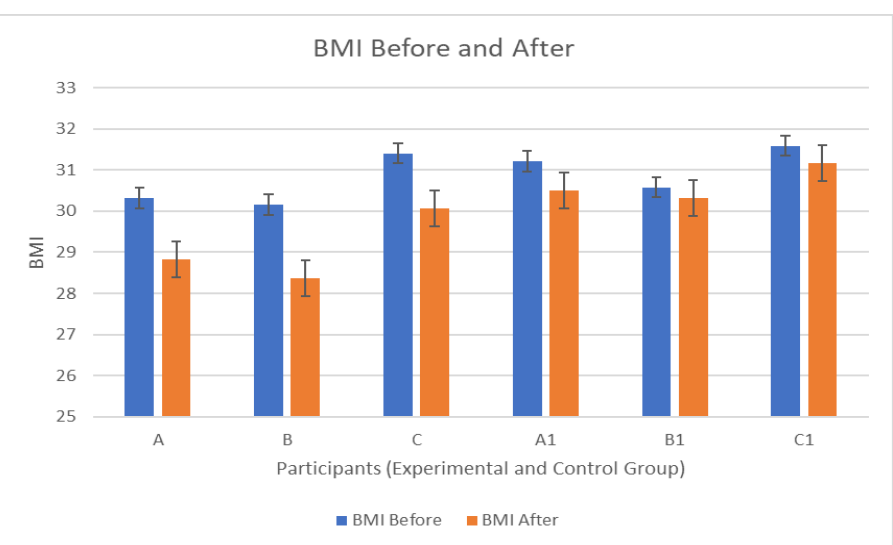

Figure 2. BMI before and after Ramadhan

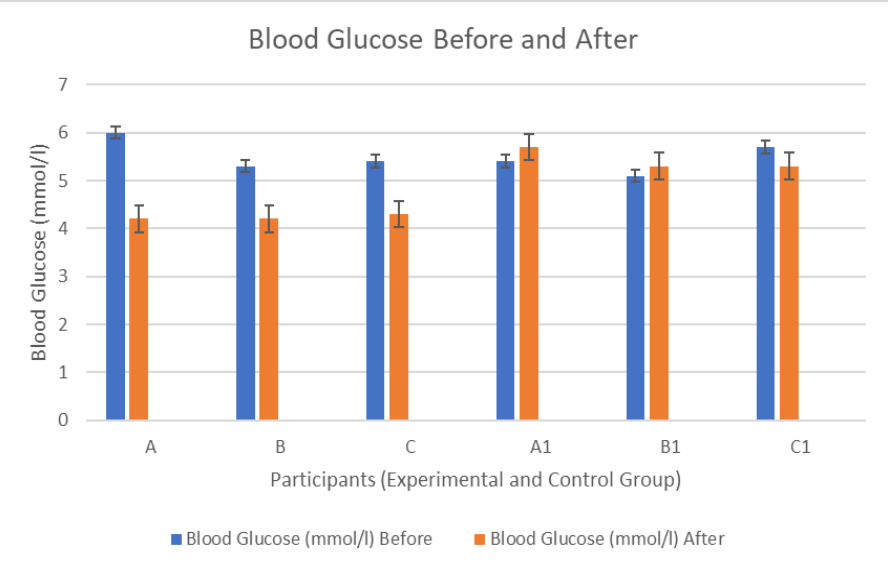

Figure 4. Blood glucose before and after Ramadhan

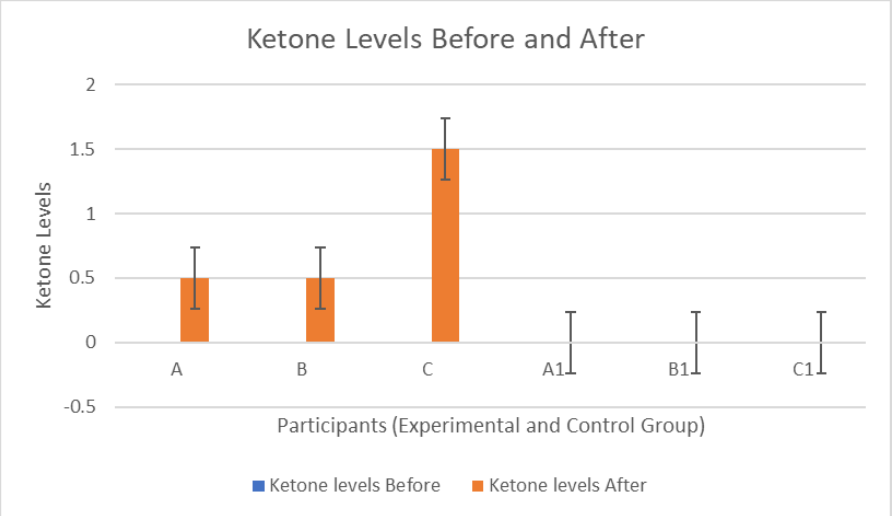

Figure 5. Ketone levels before and after Ramadhan

Table 5. Analysis of the parameters before and after Ramadan for the experimental group

\begin{tabular}{lcccc}
\hline & $\mathrm{n}=3$ & $\mathrm{~T}$ & $\mathrm{Df}$ & $\mathrm{p}$ value \\
\hline Weight Before and After & $4.90 \pm 1.01$ & 8.36 & 2 & 0.014 \\
BMI Before and After & $1.55 \pm 0.23$ & 11.47 & 2 & 0.008 \\
Waist Circumference Before and After & $1.73 \pm 0.25$ & 11.93 & 2 & 0.007 \\
Blood Glucose Before and After & $1.33 \pm 0.40$ & 5.71 & 2 & 0.029 \\
Ketones Levels Before and After & $-0.83 \pm 0.57$ & -2.5 & 2 & 0.130 \\
\hline
\end{tabular}

Data expressed in mean \pm standard deviation. Comparison was made using paired $t$-test and at $p<0.01$ shows the significance of this research.

Table 6. Analysis of the parameters before and after Ramadan for the control group

\begin{tabular}{lcccc}
\hline & $\mathrm{n}=3$ & $\mathrm{~T}$ & $\mathrm{Df}$ & $\mathrm{p}$ value \\
\hline Weight Before and After & $1.43 \pm 0.51$ & 4.84 & 2 & 0.040 \\
BMI Before and After & $0.47 \pm 0.22$ & 3.65 & 2 & 0.067 \\
Waist Circumference Before and After & $0.93 \pm 0.06$ & 14.00 & 2 & 0.005 \\
Blood Glucose Before and After & $-0.33 \pm 0.21$ & -0.15 & 2 & 0.893 \\
Ketones Levels Before and After & 0.00 & 0.00 & 0.00 & 0.00 \\
\hline
\end{tabular}

Data expressed in mean \pm standard deviation. Comparison was made using paired t-test, however, the results for the control group were at a $\mathrm{p}$ level of more than 0.01 which, is not significant as compared to the experimental group. 
recorded in this research. This has also led to a reduction of their BMI level from Obese I to overweight in 2 participants which, can be seen in Table 2 and statistical analysis has confirmed this (Tables 5 and 6). However, one participant (Subject C) who has the highest baseline BMI compared to Subjects A and B, maintained the same BMI level at the end of the study period.

Throughout the fasting month, participants with the KD intervention displayed a constant blood glucose levels which is attributed to higher amount of high-fat food consumption instead of carbohydrates in their meals such as the meals given in the diet intervention such as Grilled Lamb (13 g of fat) and Beef Rendang and Pecal Salad (120 g of fat). This resulted in lower dependency on glucose which prevented spikes in blood glucose level (Figure 4) that leads to the feeling of hunger, fatigue, dizziness and all other symptoms that are common during fasting of Ramadan as seen in similar research on ketogenic diet intervention (Dashti et al., 2004).

All 3 participants (Subjects A, B and C) in the experimental group showed the presence of ketone bodies through a weekly urinary test (Table 2 and Figure 5). This indicated that the ketogenic diet has a metabolic effect on these participants. The presence of ketone bodies because of fat metabolism during ketogenic diet intervention was also observed in other previous studies (Husain et al., 1987; Cheah et al., 2007). When fat is used as the main energy source, it will be converted into ketone bodies (small energy bodies) that suppress ghrelin (the main hunger hormone) in the body (Paoli et al., 2015).

As for the control group (Subjects A1, B1, C1) who did not participate in the KD intervention, they appeared to have remarkably different results compared to the experimental group. Their weight loss, BMI and waist circumference reduction were very minimal throughout the fasting month of Ramadan (Table 2, Figures 1 - 5). The controlled group's blood glucose levels were also shown to be inconsistent and there was no presence of any ketone bodies in their body system.

The findings of this study indicated that ketogenic diet can be implemented during fasting of Ramadan to overcome obesity as well as increase productivity during Ramadan and avoid common problems such as fatigue, dizziness, hunger and so on.

\section{Conclusion}

By the end of this research, a diet plan was established for Sahur and Iftar that satisfies the food intake for a ketogenic diet that is also palatable and appetizing for the selected obese IIUM students.
Bodyweight reduction can be observed in the diet intervention group but no evidence in the control group which, shows that the ketogenic diet shows a positive effect on obesity among selected obese IIUM students when conducted during Ramadan.

\section{References}

Al-Jazzaf, B. (2007). Dietary approaches for the reduction of cardiovascular disease risk in type 2 diabetes mellitus and obesity. Belfast: Queen's University, PhD Thesis.

Brook, C.G.D., Lloyd, J.K. and Wolf, H. (1972). Relation between Age of Onset of Obesity and Size and Number of Adipose Cells. The BMJ, 2, 25-27. https:// doi.org/ 10.1136/bmj.2.5804.25

Cheah, S.H., Ch'Ng, S.L., Husain, R. and Duncan, M.T. (2007). Effects of fasting during Ramadan on urinary excretion in Malaysian Muslims. British Journal of Nutrition, 63(2), 329-337. https://doi.org/10.1079/ BJN19900119

Dashti, H.M., Mathew, T.C., Hussein, T., Asfar, S.K., Behbahani, A., Khoursheed, M.A., Al-Sayer, H.M., Bo-Abbas, Y.Y. and Al-Zaid, N.S. (2004). Longterm effects of a ketogenic diet in obese patients. Experimental and Clinical Cardiology, 9(3), 200205.

Hu, T., Mills, K. T., Yao, L., Demanelis, K., Eloustaz, M., Yancy, W.S.Jr., Kelly, T.N., He, J. and Bazzano, L.A. (2012). Effects of low-carbohydrate diets versus low-fat diets on metabolic risk factors: A meta-analysis of randomized controlled clinical trials. American Journal of Epidemiology, 176 (Suppl. 7), S44-S54. https://doi.org/10.1093/aje/ kws264

Husain, R., Duncan, M.T., Cheah, S.H. and Ch'ng, S.L. (1987). Effects of fasting in Ramadan on Tropical Asiatic Moslems. British Journal of Nutrition, 58(1), 41-48. https://doi.org/10.1079/BJN19870067

Hussain, T.A., Mathew, T.C., Dashti, A.A., Asfar, S., A1 -Zaid, N. and Dashti, H.M. (2012). Effect of lowcalorie versus low-carbohydrate ketogenic diet in type 2 diabetes. Nutrition, 28(10), 1016-1021. https://doi.org/10.1016/j.nut.2012.01.016

Johnstone, A. (2015). Fasting for weight loss: An effective strategy or latest dieting trend?. International Journal of Obesity, 39, 727-33. https:// doi.org/10.1038/ijo.2014.214

Khan, A. and Khattak, M. (2009). Islamic Fasting: An Effective Strategy for Prevention and Control of Obesity. Pakistan Journal of Nutrition, 1(4), 185187. https://doi.org/10.3923/pjn.2002.185.187

Lim, K.G. (2016). A Review of Adult Obesity Research 
in Malaysia. The Medical Journal of Malaysia. 71 (Suppl. 1), 1-19.

Paoli, A., Bosco, G., Camporesi, E.M. and Mangar, D. (2015). Ketosis, ketogenic diet and food intake control: A complex relationship. Fronteirs in Psychology, 6, 27. https://doi.org/10.3389/ fpsyg.2015.00027

Stafstrom, C.E. and Rho, J.M. (2012). The Ketogenic Diet as a Treatment Paradigm for Diverse Neurological Disorders. Frontiers in Pharmacology, 3, 59. https://doi.org/10.3389/fphar.2012.00059 